\title{
Információ-technológiai szolgáltató vállalkozások kiegészítő mellékletének összehasonlító elemzése
}

\section{Magyarországon}

\section{Comparative analysis of the notes on the accounts of information-technology servicing companies in}

\section{Hungary}

\author{
V. FENYVES ${ }^{1}$, Z. BÁCS ${ }^{2}$, Z. ZÉMAN3, E. BÖCSKEI4, T. TARNóCZI ${ }^{5}$ \\ ${ }^{1}$ Debreceni Egyetem, Gazdaságtudományi Kar, Számviteli és Pénzügyi Intézet, fenyves.veronika@econ.unideb.hu \\ 2Debreceni Egyetem, Gazdaságtudományi Kar, Számviteli és Pénzügyi Intézet, bacs.zoltan@econ.unideb.hu \\ ${ }^{3}$ Szent István Egyetem, Gazdaság- és Társadalomtudományi Kar, Üzleti Tudományok Intézete, \\ zeman.zoltan@gtk.szie.hu \\ ${ }^{4}$ Budapesti Műszaki és Gazdaságtudományi Egyetem, Gazdaság- és Társadalomtudományi Kar, Üzleti \\ Tudományok Intézet, dr.bocskei.elvira@gmail.com \\ ${ }^{5}$ Debreceni Egyetem, Gazdaságtudományi Kar, Számviteli és Pénzügyi Intézet, tarnoczi.tibor@econ.unideb.hu
}

Absztrakt. Napjaink globalizált és felgyorsult világában a kihívásoknak az a vállalat tud megfelelni, amely rendelkezik a szükséges információkkal és azt gyorsan képes szervezeti tudássá konvertálni. A vállalatok közötti gazdasági kapcsolatokban nagyon fontos információs forrás a számviteli beszámoló. A számviteli beszámoló két alapvető részéből, a mérlegből és az eredmény-kimutatásból, akkor lehet a szükséges információhoz jutni, ha a kiegészítő melléklet tartalmazza azokat az információkat, amelyek hozzájárulnak a beszámoló másik részének a jobb értelmezéséhez. A nem megfelelő tudásra épülő döntéshozatal tovább növeli az egyébként sem alacsony gazdasági kockázatokat.. Kutatásunkban azt vizsgáljuk, hogy a vállalatok által elkészített kiegészítő mellékletek tartalmazzák-e azokat az információkat, amelyek segítségével a partner vállalatokra vonatkozó szükséges pénzügyi ismeretek megszerezhetők. A vizsgálathoz a 62-es TEÁOR számú, fötevékenységként Információtechnológiai szolgáltatás tevékenységet megadó vállalatokat kiegészítő mellékleteit használtuk fel. Szövegbányászat segítségével azt vizsgáljuk, hogy a kiegészítő mellékletek mennyiben felelnek meg a számviteli törvény általi előírásoknak.

Abstract. In the globalized and accelerated world of our time, challenges can only be met by companies that possess the necessary information and are able to convert it rapidly into organizational knowledge. Annual accounting statements are an important source of information within business relations among companies. The necessary information can only be obtained from the two fundamental parts of the annual statements (balance sheet and profit and loss account) if the notes on the account contains the information that contribute to the more comprehensive interpretation of the other parts of the annual statement. Decision-making based on inadequate knowledge further increases economic risks that are already high. In our research, we examine whether the notes on 
the accounts of companies include the information, which could help obtain necessary financial knowledge concerning the partner companies. For the analyses, we used the notes on the accounts of companies, which have information-technology services (Hungarian NACE No. 62) as their main line of business. By means of text mining, we analyse the extent to which the notes on the accounts are in conformity with the Accounting Act.

\section{Bevezetés}

Napjaink globalizált és felgyorsult világában a vállalatok közötti verseny is sokkal erőteljesebbé vált. Ebben a világban a döntéshozatal szempontjából két dolog kap kiemelkedő szerepet az információ, a tudás és a gyorsaság. Egy vállalat sikeres múködésének elengedhetetlen feltétele a tájékozottság. Mindez azt jelenti, hogy a kihívásoknak az a vállalat tud megfelelni, amely rendelkezik a szükséges információkkal és azt gyorsan képes szervezeti tudássá konvertálni. A tájékozottsághoz, ahhoz, hogy a vállalkozások megítélhetőek és értékelhetőek legyenek egy megbízható és egységes információs rendszerre van szükség mind a vállalkozás, mind a környezete számára. Ezt az igényt elégíti ki a vállalkozások számvitele, mely hazánkban a számvitelről szóló 2000. évi C törvényben jelenik meg. A számvitel egyik oldalról megközelítve egy belső információs rendszer, míg más oldalról nézve fő feladata a külső környezet felé az információk szolgáltatása a törvényi előírásokkal összhangban [1]. A számviteli törvény határozza meg a hatálya alá tartozók könyvvezetési és beszámolási kötelezettségeit, a könyvek vezetése és a beszámoló összeállítása során kötelezően érvényesítendő elveket, az ezekre épített szabályokat, továbbá a nyilvánosságra hozatali, közzétételi és könyvvizsgálati kötelezettségeket [2]. Ezek biztosítják a piaci szereplők számára az elkészített beszámoló megbízható és valós összképet biztosító tájékoztatás nyújtását vagyoni helyzetéről, eszközeiről és forrásairól, az azokban bekövetkezett változásokról, pénzügyi és jövedelmezőségi helyzetéről, illetve jövőbeli terveiről [3]. A kiegészítő mellékletnek nincs a mérleghez és az eredménykimutatáshoz hasonló, törvény által előírt struktúrája, ezért ritkán lehet ugyanazon felépítéssel és tartalommal találkozni, de alapvetően minden esetben három részből tevődik össze [4]. Az általános részében a jogi környezet (a vállalkozó alapadatai: főtevékenység, székhely, telephely, tulajdonosok, vezetők, képviselők, regisztrált könyvelő, választott könyvvizsgáló), valamint a számviteli politika fő vonásai (beszámoló célja, fajtája, fordulónap, mérlegkészítés napja, üzleti év, a mérleg és az eredménykimutatás választott változata; alkalmazott értékelési eljárások, árfolyam, a könyvelés pénzneme) kerülnek bemutatásra. A specifikus részében találjuk a vagyon, a pénzügyi és jövedelmi helyzetet jellemző mutatószámokat (megoszlási és dinamikus viszonyszámokat), a befektetési tükröt, a saját tőke változásának részletezését, az időbeli elhatárolások előfordulásának bemutatását, továbbá a társasági adó alapjának levezetését. A tájékoztató részében a foglalkoztatottak létszáma, a vezető tisztségviselők, az igazgatóság, a felügyelőbizottság tagjainak tevékenységükért az üzleti év után járó járandóság összege, a részükre folyósított előlegek és kölcsönök összege és a nevükben vállalt garanciák, valamint a korábbi vezető tisztségviselőivel, igazgatósági, felügyelőbizottsági tagjaival szembeni nyugdíjfizetési kötelezettség teljes összege kerül bemutatásra. Ebben a részben kell említést tenni az esetleges perek állásáról, a visszavásárolt saját részvények, üzletrészek nagyságról, illetve az össze nem hasonlítható adatokról (pl. ha egymást követő üzleti 
években nem azonos változat szerint készíti a mérleget), valamint az eszközök és a források minősítésének megváltozásáról.

A vállalkozások versenyképessége nagymértékben függ az információs és döntési rendszerük hatékonyságától, a megfelelő helyen és időben rendelkezésre álló releváns információktól. A számviteli információs rendszer a gazdasági események számviteli előírásoknak megfelelő rögzítésén túlmenően ki tudja elégíteni a külső és belső érdekhordozók információs igényeit. Elmondható, hogy a vállalati közötti gazdasági kapcsolatokban nagyon fontos információs forrás a számviteli beszámoló [5]. Ugyanakkor látni kell, hogy a számviteli beszámoló két alapvető részéből, a mérlegből és az eredmény-kimutatásból, azok aggregált jellegéből adódóan, akkor lehet a szükséges információhoz, és azon keresztül a szükséges tudáshoz jutni, ha a számviteli beszámoló harmadik része, a kiegészítő melléklet tartalmazza azokat az információkat, amelyek hozzájárulnak a beszámoló másik ét részének a jobb értelmezéséhez. A kellő információval bíró kiegészítő melléklet nélkül a mérleg és az eredménykimutatás hatékony felhasználása is problémás lehet. Ferencz véleménye, hogy a kiegészítő melléklet lenne hivatott segítséget nyújtani az adatok értelmezésében, azonban ez nem feltétlen valósul meg a gyakorlatban [6]. Kántor tanulmányában is megfogalmazza, hogy a mai napig van olyan gazdálkodó, aki csak felületesen mutatja be a mérleg és az eredménykimutatás egyes értékeit (ha egyáltalán bemutatja), mert fél, hogy a versenytársai tényszerű információkat tudhatnak meg abból a tevékenységről, eredményességéről. A hatályos jogszabályok értelmében azonban a kiegészítő melléklet elkészítése - bizonyos elemektől eltekintve - kötelező, annak adat- és információtartalma szabályozott, ebből következően az összeállítására és a megfelelő információk közlésére a beszámolókészítés alkalmával kellő időt és energiát kell szentelnie mind az ügyvezetésnek, mind a könyvviteli feladatokat ellátó szakember(ek)nek [7]. Tóthné vizsgálata alapján megállapította hogy a kiegészítő melléklet minőségét javítani szükséges [8].

Azt is látni kell, hogy a nem megfelelő tudásra épülő döntéshozatal tovább növeli az egyébként sem alacsony gazdasági kockázatokat. Ugyanakkor a számviteli beszámolóknak éppen ahhoz kellene segítséget nyújtaniuk, hogy a megalapozottabb döntéshozatal által csökkenjen a kockázat. Tanulmányunkban azt mutatjuk be egy ágazat vizsgálatán keresztül, hogy a kiegészítő mellékletek milyen mértékben biztosítják azokat az információkat, amelyek a mérleg és az eredmény-kimutatás megfelelő értelmezéséhez elengedhetetlenül szükségesek lennének.

A Szövegbányászat segítségével azt vizsgáljuk, hogy a kiegészítő mellékletek mennyiben felelnek meg a számviteli törvény általi előírásoknak.

\section{Anyag és módszer}

A vizsgálathoz olyan magyarországi vállalatok kiegészítő mellékleteit vizsgáltuk, amelyek TEÁOR 62es számú, főtevékenységként Információ-technológiai szolgáltatás tevékenységet végző vállalatok. Az adatbázisba azok a vállalkozások kerültek, akik 2016-os évre vonatkozóan számviteli beszámolót tettek közzé, összesen 11476 vállalat, ebből 8858 vállalat rendelkezett kiegészítő melléklettel (a többi szervezet vagy nem töltött fel kiegészítő mellékletet vagy mikrogazdálkodói beszámoló készítésére kötelezett, amelynek nincsen kiegészítő melléklet része), amiből 8226 (92,87\%) vállalat kiegészítő 
mellékletét tudtuk feldolgozni. Az elemzést az R statisztikai rendszer különböző csomagjainak a felhasználásával végeztük. Szövegbányászat segítségével azt vizsgáljuk, hogy a kiegészítő mellékletek milyen mértékben biztosítják azokat az információkat, amelyek a mérleg és az eredmény-kimutatás megfelelő értelmezéséhez, használatához elengedhetetlenül szükségesek lennének.

Az elmúlt két évtizedben a szövegbányászat egyre nagyobb érdeklődésre tett szert úgy az akadémiai területen, mint az üzleti intelligencia alkalmazásokban. A szövegbányászat azt a képességet jelenti, hogy nagy mennyiségű strukturálatlan szöveget feldolgozva, gyorsan jutunk hasznos és újszerű ismeretekhez, amelyek befolyásolhatják az érintettek döntéshozatalát. Van olyan megfogalmazás is, hogy a szövegbányászat az a feldolgozási folyamat, amelynek során cselekvőképes betekintést nyerhetünk a szövegbe [9]. Egyre több olyan szövegszerű adatbázis keletkezik számítógéppel olvasható formátumban, amelyeket gyorsan kell feldolgozni. A szövegbányászat interdiszciplináris kutatási terület, amely felhasználja a számítógép-tudomány, a nyelvészet és statisztika különböző eszközeit [10]. Minden mennyiségi kutatás, mint amilyenek az üzleti területtel foglalkozó tudományok is, statisztikai módszereket használnak, amelyekhez strukturált információk összegyűjtésére van szükség [11]. Az R statisztikai rendszer 'tm' programcsomagja olyan infrastruktúrát biztosít, amely lehetővé teszi, hogy hatékonyan dolgozhassunk szövegekkel, az azokhoz kapcsolható metaadatokkal, és hogy átalakíthassuk a szövegeket strukturált reprezentációkká, amelyeken már alkalmazhatók a szükséges statisztikai módszerek is [12]. A 'tm' csomag lehetővé teszi azt is, hogy különböző formátumú szövegeket dolgozzunk fel (txt, doc, pdf, csv, stb.). Az elemzésre szánt szövegek elemzése olyan feladatok végrehajtását követeli meg, amelyek befolyásolhatják a szövegelemzési vizsgálat pontosságát, érvényességét és megállapításait, csakúgy, mint az elemzéshez használt technikákat [13].

\section{Információ-technológiai szolgáltató vállalkozások kiegészítő mellékletének összehasonlító elemzése}

A vizsgált 8226 db vállalkozás kiegészítő mellékletét megvizsgáltuk beszámolótípus szempontjából (1. táblázat). A beszámolótípus szempontjából 1056 (12,8\%) gazdálkodó szervezet nem szereltette a kiegészítő mellékletében, hogy milyen típusú beszámolót készít, 6432 db (78,2\%) gazdálkodó szervezet egyszerűsített éves beszámolót és 738 db (9\%) szervezet éves beszámolót készített a vizsgált időszakban.

\begin{tabular}{|l|r|r|}
\hline \multicolumn{1}{|c|}{ Beszámoló típusa } & \multicolumn{1}{c|}{ db } & \multicolumn{1}{c|}{ \% } \\
\hline Nem adott meg & 1056 & $12,84 \%$ \\
\hline Egyszerűsített éves beszámoló & 6432 & $78,19 \%$ \\
\hline Éves beszámoló & 738 & $8,97 \%$ \\
\hline Összesen & 8226 & $100,00 \%$ \\
\hline
\end{tabular}

1. táblázat: A vizsgált kiegészítô mellékletek számának alakulása beszámolótípus szerinti bontásban (M.e.: db)

A beszámolótípus mellett a cégtípus szerinti vizsgálat alapján megállapítható (2. táblázat), hogy 195 vállalkozás nem szerepeltette a cégformáját a kiegészítő mellékletében, a vállalkozások 70,86 \%-a korlátolt felelősségű társaság, 26\%-a betéti társaság és 7,53\%-a részvénytársaság volt a mintában. 


\begin{tabular}{|l|r|r|}
\hline \multicolumn{1}{|c|}{ Cégtípus } & \multicolumn{1}{c|}{ db } & \multicolumn{1}{c|}{ \% } \\
\hline Nem adott meg & 195 & $2,37 \%$ \\
\hline Bt. & 2140 & $26,02 \%$ \\
\hline Kft. & 5829 & $70,86 \%$ \\
\hline Rt. & 62 & $0,75 \%$ \\
\hline Összesen & 8226 & $100,00 \%$ \\
\hline
\end{tabular}

2. táblázat: A vizsgált kiegészítô mellékletek számának alakulása cégtípus szerinti bontásban (M.e.: db)

Megvizsgáltuk a kiegészítő mellékletek terjedelmét, ezt láthatjuk az 1. ábrán. A kiegészítő melléklet terjedelmével kapcsolatban semmilyen jogszabályi elő́rás nem rendelkezik, korábbi vizsgálatok kimutatták már a terjedelem és a minőség közötti összefüggést. Tóthné vizsgálatai alapján az általa vizsgált minta terjedelmének megoszlása a következő volt: 40\%-a 21 és 50 oldal közötti, de 33\%-a csak 11 és 20 oldal közötti terjedelmű [8]. A terjedelem és a minőség közötti összefüggés a minta alapján egyértelműen levezethetővé vált. A kutatásunkban vizsgált kiegészítő mellékletek közül 1-5 oldal közötti terjedelmű 3381 db (41\%), 6-10 oldal terjedelmű 3539 db (43\%), 11-20 oldal trejedelmú $1228 \mathrm{db}(15 \%), 21-50$ oldal terjedelmü $75 \mathrm{db}(1 \%)$ és 50 oldal feletti terjedelmú volt összesen $3 \mathrm{db}(0,04 \%)$ kiegészítő melléklet.

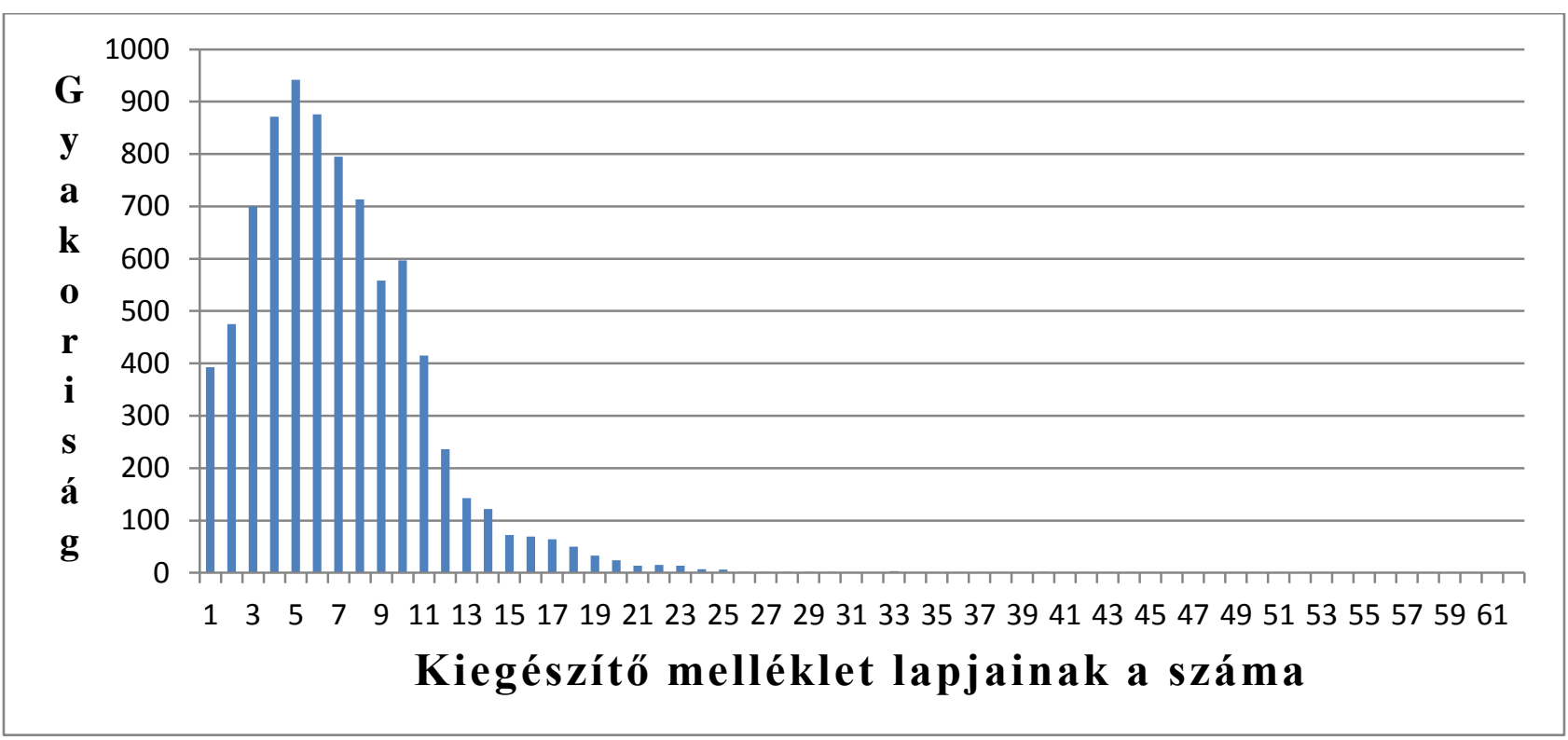

1. ábra: A vizsgált kiegészítő mellékletek lapjainak száma (M.e.: db)

A 2000. évi C. törvény a számvitelről megfogalmazza, hogy a kiegészítő mellékletbe azokat a számszerű adatokat és szöveges információkat kell felvenni, amelyeket

- a számviteli törvény előír,

- továbbá mindazokat, amelyek a vállalkozó vagyoni, pénzügyi helyzetében, múködése eredményének megbízható és valós bemutatásához a tulajdonosok, a befektetők, a hitelezők számára - a mérlegben, az eredménykimutatásban szereplő információkon túlmenően szükségesek [14]. 
A számviteli törvény tartalmazza azokat az információkat, amelyeket a kiegészítő mellékletbe be kell mutatni, de nem csoportosítja őket. A számviteli törvényben a kiegészítő melléklet adattartalmára vonatkozóan az egyes részekhez kapcsolódó információk ömlesztve vannak felsorolva. Az éves beszámoló esetében a gyakorlat szempontjából azonban célszerű ezeket az információkat három nagy részre osztani. Ennek megfelelően megkülönbözethetünk:

- általános részt, amely alapvetően a beszámolóban szereplő adatok könnyebb megértését hivatott szolgálni

- A tájékoztató részt, a mely a vállalkozás múködéséhez kapcsolható, a vállalkozás helyzetének részletes megértését segíti elő, illetve

- A specifikus részt, amelyben az információk a mérlegben és az eredménykimutatásban szereplő számszaki adatokhoz kapcsolódnak, azok részletezését, magyarázatát mutatják be [7].

Jelen tanulmányban a tájékoztató részhez tartozó információk kiegészítő mellékletben való megjelenését mutatjuk be a főtevékenységként információ technológiai szolgáltatással foglalkozó vállalkozások esetében (3. táblázat) összességében és a beszámoló típusa szerinti megbontásban. Ahogy az előbbiekben is megfogalmaztuk a számviteli törvény nem írja elő kötelezően a gazdálkodó szervezetek számára, hogy szerepeltessen ún. „Tájékoztató részt” a kiegészítő mellékletében, azt viszont megfogalmazza, hogy szerepeltesse azokat az információkat. amelyek alapvetően a beszámolóban szereplő adatok könnyebb megértését hivatottak szolgálni. Megnéztük, hogy hány gazdálkodó szervezet szereltette mégis a tájékoztató rész kifejezést a kiegészítő mellékletében. A vizsgált minta 68,13\%-a nem tartalmazott, és 31,87\% (2622 db) tartalmazott külön tájékoztató részt a kiegészítő mellékleten belül. Ezzel alapvetően még nincsen probléma, hiszen ahogy az előzőekbe olvastuk, ez nem kötelező eleme a kiegészítő mellékletnek.

A számviteli törvényben szereplő előírások a következőket tartalmazzák még:

- A foglalkoztatottak létszámmal kapcsolatos információk. A vizsgált $8226 \mathrm{db}$ gazdálkodó szervezetből 1503 szervezet adta meg a foglalkoztatottak létszámát, azaz a minta 31,87\%-a, amelyen belül 15,05\% az egyszerűsített éves beszámolót készítők aránya.

- Vezető tisztségviselőkkel kapcsolatos infromációkat 1667 vállalkozás szerepeltett a kiegészítő mellékletében, amely a mint 20,27\%-át adta.

- Igazgatósággal kapcsolatos információkat 477 vállalkozás szerepeltett, ami mindössze 5,5\%-át jelentette a mintának.

- Felügyelőbizottsággal kapcsolatos információk a minta 10,64\%-ában szerepletek (875 db)

- Mérlegen kívüli tételekkel kapcsolatos információk 1378 (16,75\%) kiegészítő mellékletben volt található.

- Veszélyes hulladékkal kapcsolatos információk 3730 db (45,34\%) kiegészítő mellékletben szerepeltek.

- Környezetre káros anyaggal kapcsolatos információkat 1729 (21,02\%) kiegészítő melléklet szerepeltetett.

- Környezetvédelmi kötelezettséggel kapcsolatos információk 1941 (23,6\%) kiegészítő mellékletben találhatóak meg. 


\begin{tabular}{|c|c|c|c|c|c|c|c|c|}
\hline \multirow{3}{*}{ Keresett kifejezés } & \multirow{2}{*}{\multicolumn{2}{|c|}{ Összesen }} & \multicolumn{6}{|c|}{ Beszámoló típusa } \\
\hline & & & \multicolumn{2}{|c|}{ Nem adott meg } & \multicolumn{2}{|c|}{$\begin{array}{c}\text { Egyszerüsített } \\
\text { éves }\end{array}$} & \multicolumn{2}{|c|}{ Éves } \\
\hline & $\mathbf{d b}$ & $\%$ & db & $\%$ & $\mathbf{d b}$ & $\%$ & $\mathbf{d b}$ & $\%$ \\
\hline Vizsgált cégek & 8226 & $100 \%$ & 1056 & $100 \%$ & 6432 & $100 \%$ & 738 & $100 \%$ \\
\hline Tájékoztató rész & 2622 & $31,87 \%$ & 234 & $2,84 \%$ & 2203 & $26,78 \%$ & 185 & $2,25 \%$ \\
\hline $\begin{array}{l}\text { Foglalkoztatottak } \\
\text { létszámmal } \\
\text { kapcsolatos } \\
\text { információk }\end{array}$ & 1503 & $18,27 \%$ & 114 & $1,39 \%$ & 1238 & $15,05 \%$ & 151 & $1,84 \%$ \\
\hline $\begin{array}{l}\text { Vezető } \\
\text { tisztségviselőkel } \\
\text { kapcsolatos } \\
\text { információ }\end{array}$ & 1667 & $20,27 \%$ & 253 & $3,08 \%$ & 1266 & $15,39 \%$ & 148 & $1,80 \%$ \\
\hline $\begin{array}{l}\text { Igazgatósággal } \\
\text { kapcsolatos } \\
\text { információ }\end{array}$ & 477 & $5,80 \%$ & 25 & $0,30 \%$ & 357 & $4,34 \%$ & 95 & $1,15 \%$ \\
\hline $\begin{array}{l}\text { Felügyelőbizottsággal } \\
\text { kapcsolatos } \\
\text { információk }\end{array}$ & 875 & $10,64 \%$ & 127 & $1,54 \%$ & 639 & $7,77 \%$ & 109 & $1,33 \%$ \\
\hline $\begin{array}{l}\text { Mérlegen kívüli } \\
\text { tételekkel } \\
\text { kapcsolatos } \\
\text { információk }\end{array}$ & 1378 & $16,75 \%$ & 160 & $1,95 \%$ & 1115 & $13,55 \%$ & 103 & $1,25 \%$ \\
\hline $\begin{array}{l}\text { Veszélyes } \\
\text { hulladékkal } \\
\text { kapcsolatos } \\
\text { információk }\end{array}$ & 3730 & $45,34 \%$ & 407 & $4,95 \%$ & 3054 & $37,13 \%$ & 269 & $3,27 \%$ \\
\hline $\begin{array}{l}\text { Környezetre káros } \\
\text { anyaggal kapcsolatos } \\
\text { információk }\end{array}$ & 1729 & $21,02 \%$ & 271 & $3,29 \%$ & 1311 & $15,94 \%$ & 147 & $1,79 \%$ \\
\hline $\begin{array}{l}\text { Környezetvédelmi } \\
\text { kötelezettséggel } \\
\text { kapcsolatos } \\
\text { információk }\end{array}$ & 1941 & $23,60 \%$ & 270 & $3,28 \%$ & 1511 & $18,37 \%$ & 160 & $1,95 \%$ \\
\hline
\end{tabular}

3. táblázat: A tájékoztató részhez tartozó elemek megjelenése a beszámoló típusa alapján a kiegészító mellékletekben (M.e.: db)

A Vezető tisztségviselőkkel, az igazgatósággal és a felügyelőbizottsággal kapcsolatos információkat megvzsgáltuk külön cégtípus szerinti bontásban is.

- Vezető tisztségviselőkkel kapcsolatos infromációkat megadó 1667 vállalkozás 73,19\%-a korlátolt felelősségű társaság volt

- Igazgatósággal kapcsolatos információkat szerepeltető 477 vállalkozás 76,31\%- a korlátolt felelősségű társaság volt.

- Felügyelőbizottsággal kapcsolatos információkat szerepeltető 875 válllakozás 71,43\%-a korlátolt felelősségű társaság volt. 


\begin{tabular}{|c|c|c|c|c|c|c|c|c|c|c|}
\hline \multirow{3}{*}{ Keresett kifejezés } & \multirow{2}{*}{\multicolumn{2}{|c|}{ Összesen }} & \multicolumn{8}{|c|}{ Cégtípus } \\
\hline & & & \multicolumn{2}{|c|}{$\begin{array}{l}\text { Nem adott } \\
\text { meg }\end{array}$} & \multicolumn{2}{|c|}{ Bt } & \multicolumn{2}{|c|}{ Kft } & \multicolumn{2}{|c|}{ Rt } \\
\hline & $\mathrm{db}$ & $\%$ & db & $\%$ & $\mathbf{d b}$ & $\%$ & $\mathbf{d b}$ & $\%$ & $\mathrm{db}$ & $\%$ \\
\hline Vizsgált cégek & 8226 & $100 \%$ & 195 & $2,37 \%$ & 2140 & $\begin{array}{c}26,02 \\
\%\end{array}$ & 5829 & $\begin{array}{l}70,8 \\
6 \%\end{array}$ & 62 & $\begin{array}{c}0,75 \\
\%\end{array}$ \\
\hline $\begin{array}{l}\text { Vezető } \\
\text { tisztségviselőkel } \\
\text { kapcsolatos } \\
\text { információ }\end{array}$ & 1667 & $20,27 \%$ & 46 & $0,56 \%$ & 386 & $4,69 \%$ & 1220 & $\begin{array}{r}14,8 \\
3 \%\end{array}$ & 15 & $\begin{array}{r}0,18 \\
\%\end{array}$ \\
\hline $\begin{array}{l}\text { Igazgatósággal } \\
\text { kapcsolatos } \\
\text { információ }\end{array}$ & 477 & $5,80 \%$ & 13 & $0,16 \%$ & 94 & $1,14 \%$ & 364 & $\begin{array}{r}4,42 \\
\%\end{array}$ & 6 & $\begin{array}{r}0,07 \\
\%\end{array}$ \\
\hline $\begin{array}{l}\text { Felügyelőbizpttságg } \\
\text { al kapcsolatos } \\
\text { információk }\end{array}$ & 875 & $10,64 \%$ & 38 & $0,46 \%$ & 206 & $2,50 \%$ & 625 & $\begin{array}{r}7,60 \\
\% \\
\end{array}$ & 6 & $\begin{array}{r}0,07 \\
\% \\
\end{array}$ \\
\hline
\end{tabular}

4. táblázat: A tájékoztató részhez tartozó elemek megjelenése cégtípus alapján a kiegészítő mellékletekben (M.e.:

db)

\section{Következtetések}

A 2000. évi C. törvény a számvitelről kimondja, hogy „A piacgazdaság működéséhez nélkülözhetetlen, hogy a piac szereplői számára hozzáférhetően, döntéseik megalapozása érdekében mind a vállalkozók, mind a nem nyereségorientált szervezetek, valamint az egyéb gazdálkodást folytató szervezetek vagyoni, pénzügyi és jövedelmi helyzetéről és azok alakulásáról objektív információk álljanak rendelkezésre." Ezt a célt szolgálja az éves beszámoló részét képző kiegészítő melléklet is, mindezek alapján megállapítható, hogy a kiegészítő melléklet információja a beszámoló komplex megértéséhez nagyon fontos lenne a különböző piaci szereplők, érdekeltek, mint felhasználók számára. Egy gazdálkodó szervezet sikeres működésének elengedhetetlen feltétele a tájékozottság, a döntéshozatal szempontjából kiemelkedő szerepet kap az információ, a tudás és a gyorsaság. A nem megfelelő tudásra épülő döntéshozatal tovább növeli az egyébként sem alacsony gazdasági kockázatokat. Ugyanakkor a számviteli beszámolóknak éppen ahhoz kellene segítséget nyújtaniuk, hogy a megalapozottabb döntéshozatal által csökkenjen a kockázat, mert megfelelő információkkal ellátott kiegészítő mellékletek segítenék, biztosítanák a piaci szereplők megfelelő tájékozottságát. Az általunk vizsgált 8226 db kiegészítő melléklet esetében elmondhatjuk, hogy a vizsgált tájékoztató részhez tartozó törvényi előírások mindegyikében hiányosságot mutattak. A vizsgált gazdasági szervezetek kiegészítő mellékletének tájékoztató információi nem felelnek meg a számviteli törvény előírásainak, ezáltal esetüknek nem teljesül a piaci szereplők tájékoztatási kötelezettsége a vállalkozások gazdálkodásának megbízható és valós összképének bemutatásáról.

\section{Köszönetnyilvánítás}

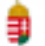

Az Emberi Erőforrások Minisztériuma ÚNKP-17-4. kódszámú Új Nemzeti Kiválóság Programjának támogatásával készült" 


\section{Hivatkozások}

[1] D. Kerezsi (2017) A kiegészítő melléklet szerepe a piaci szereplők tájékoztatásában. International Journal of Engineering and Management Sciences / Müszaki és Menedzsment Tudományi Közlemények. 2 (4) pp. 202-222.

[2] E. Böcskei (2014) A számviteli politika előtérbe kerülése - a belső számvitel információtartalma, mint a vezetói számvitel alapja. Controller Info, 2 (2) pp. 38-43.

[3] Z. Musinszki (2016) Pénzügyi mutatókon innen és túl. Észak-Magyarországi Stratégiai Füzetek, 13 (2) pp. 71-80.

[4] J. Filyó (2014) A kiegészítő melléklet ellenőrzésének tapasztalatai. Számvitel, adó könyvvizsgálat, 56 (6) pp. 285-286.

[5] Z. Musinkszki (2012) A számviteli információ és a vezetői számvitel alapjai http://gtk.unimiskolc.hu/files/9140/A+vezet\%C5\%91i+sz\%C3\%A1mvitel+alapjai+k\%C3\%A9zirat.pdf letöltés: 2018.04.06

[6] O. Ferencz (2013) Az egyszerűsített éves beszámoló mint információhordozó. Számvitel, adó, könyvvizsgálat, 55 (9) 425. p.

[7] B. Kántor (2016) A kiegészítő melléklet. Számviteli tanácsadó, 8 (3) pp. 2-11.

[8] E. Tóthné Szabó (2012) A kiegészítő melléklet szerepe és tartalma a számviteli információ hordozta "megbízható és valós kép" kialakításában. Sopron: Nyugat-magyarországi Egyetem Közgazdaságtudományi Kar. (Doktori értekezések) (ISBN:978-963-334-072-1) 132 p.

[9] T. Kwartler (2017) Text Mining in Practice with R. John Wiley and Sons, Ltd. 2017. ISBN: 978-1119-28201-3

[10] I. Feinerer (2008) An introduction to text mining in $R$. R News, 8 (2) pp. 19-22. On-line: http://CRAN.R-project.org/doc/Rnews/ Letöltés dátuma: 2018.03.20

[11] S. Munzert - C. Rubba - P. Meißner - D. Nyhuis (2014) Automated Data Collection with R: A Practical Guide to Web Scraping and Text Mining. John Wiley and Sons, Ltd. ISBN: 978-1-11883481-7

[12] I. Feinerer - K. Hornik - D. Meyer (2008) Text mining infrastructure in R. Journal of Statistical Software, 25 (5) pp. 1-54. ISSN 1548-7660.

[13] K. Welbers - W. Van Atteveldt - K. Benoit (2017) Text Analysis in R. Communications Methods and Measures, 11 (4) pp. 245-265. On-line:https://doi.org/10.1080/ 19312458.2017.138723 Letöltés dátuma: 2018.03.20

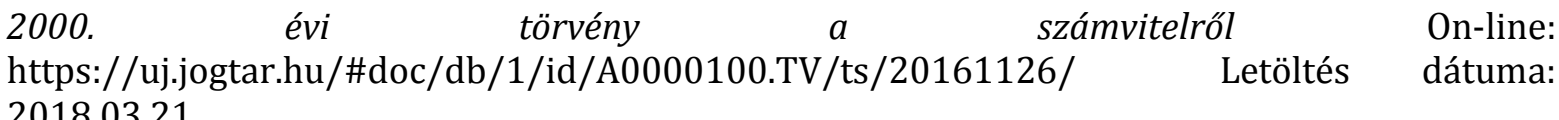

